\title{
Growth performance of tilapia fingerling in cage in ponds managed by Adivasi households: An assessment through length-weight relationship
}

\author{
N. Gupta, M. M. Haque and M. Khan \\ Department of Aquaculture, Bangladesh Agricultural University, Mymensingh-2202, Bangladesh \\ E-mail: nipa_hstu@yahoo.com
}

\begin{abstract}
This study was conducted to assess the growth performances of cage reared GIFT strain of tilapia (Oreochromis niloticus) fingerling using length-weight (LW) relationship technique. Along with this, condition factor (K) of fish and pond water quality parameters were also brought under this study to have broader understanding. For LW relationship and $\mathrm{K}$, a sample size of 120 fingerlings was made from randomly selected three different cages in a pond at Tarala village in Kaharole Upazila of Dinajpur District, Bangladesh. The length-weight relationship of tilapia fingerlings reared in cages managed by Adivasi people was significant. The value of correlation coefficient $(r)$ and the coefficient of determination $\left(r^{2}\right)$ were 0.97 and 0.94 respectively. This suggests that growth of tilapia from fry to fingerling was normal in cages. The condition factor of different size group of fish was almost closed to 2 , indicating fish health as satisfactory. All the water quality parameters including temperature, transparency, dissolved oxygen, ammonia-nitrogen, phosphate-phosphorus, nitrate-nitrogen and $\mathrm{pH}$ were within suitable range both in cages and outside the cage in pond. About 5 phyla and 25 genera of phytoplankton from Bacillariophyceae, Cyanophyceae, Chlorophyceae, Euglenophyceae and Rhodophyceae groups and one phylum and 5 genera of zooplankton from Rotifera group were found in cage installed in ponds. These all indicate the growth of tilapia fingerling in cages was satisfactory which was technically sound for landless adivasi households.
\end{abstract}

Keywords: Adivasi, cage culture, Length-weight relationship, Condition factor

\section{Introduction}

Indigenous ethnic minorities (about 2.5 million) live in clusters at different parts of the country and commonly known as adivasi who are reported to be vulnerable and far from the mainstream development in Bangladesh (Kamal et al. 2003). There are recorded 45 tribes in Bangladesh. In the northwest Bangladesh there are about 35 adivasi tribes among of whom are the Barman, Koch, Monad, Orion, Sandal, and Rajbangshi, Munda, Paharia, Malo, Karmokar, Mahato, Rajowar, Badara, Bhumij, Bhugs, Khoira, Pal, Burma etc. Then there are the other tribal peoples in north-eastern Bangladesh, including the Garo (Mandi), Hajong, Khasi and Rakhaing. The increasing trend of population growth and decreasing trend of natural resources have negatively affected adivasi's traditional livelihoods of hunting and gathering of foods from wetlands (Haque et al. 2010). And gradually changes their occupation for hunting to agriculture based day labourer. In this milieu, the WorldFish Center in collaboration with Caritas Bangladesh involved adivasi people in cage based fish fingerling production in northeast and northwest Bangladesh to uplift the livelihood condition of adivasi people.

Technically, cage culture is a profitable and one of the easy aquaculture practices. It could be operated in any types of aquatic environments. It is cheaper and affordable than other forms of aquaculture practices. It permits manipulation of harvest to fit the market demand of fingerling whenever more profitable. Thus it could be very profitable for poor farmers in Bangladesh (CARE, 2000). The growth of fish in cage in earthen ponds happens in a confined static aquatic environment that may affect the growth of fish positively or negatively. Assessing growth of fish in cage is an important prerequisite for understanding the performance of fish productivity which has implications of economic benefits and broader dissemination of this technology to the wider scale. Understanding on the growth performance of fish has different ways, of which length-weight relationship is one of them. Length-weight relationship is widely used procedure to assess the growth performances of fish. Length and weight data are useful standard results of fish sampling programmes (Morato et al. 2001). According to Mendes et al. (2004), lengthweight relationship is one of the most commonly used analyses of fisheries data. Along with length-weight 
relationship, studies on the condition factors provide a robust indication of fish health. In addition to these, general limnological aspects particularly some basic physico-chemical and biological parameters are the indicators of pond productivity. Particularly, the plankton production indicates the trophic condition of a pond system.

In the open water system, a large number of studies were undertaken to measure the growth pattern of fish, water quality parameter and plankton quality, however in cage based system how the fish grow is not well understood. The present study was undertaken to understand the growth performances of fish in cage in earthen ponds of adivasi households through length-weight relationship along with condition factor and some basic physico-chemical and biological parameters of pond water.

\section{Materials and Methods}

\section{Determining Length-Weight Relationship}

The samples of Genetically Improved Farmed Tilapia strain (GIFT) (Oreochromis niloticus) for lengthweight relationship determination were collected from the Tarala village of Kaharole upazila in Dinajpur (Fig. 1), Bangladesh which is one of the villages where WorldFish Center implemented their development project with adivasi households.

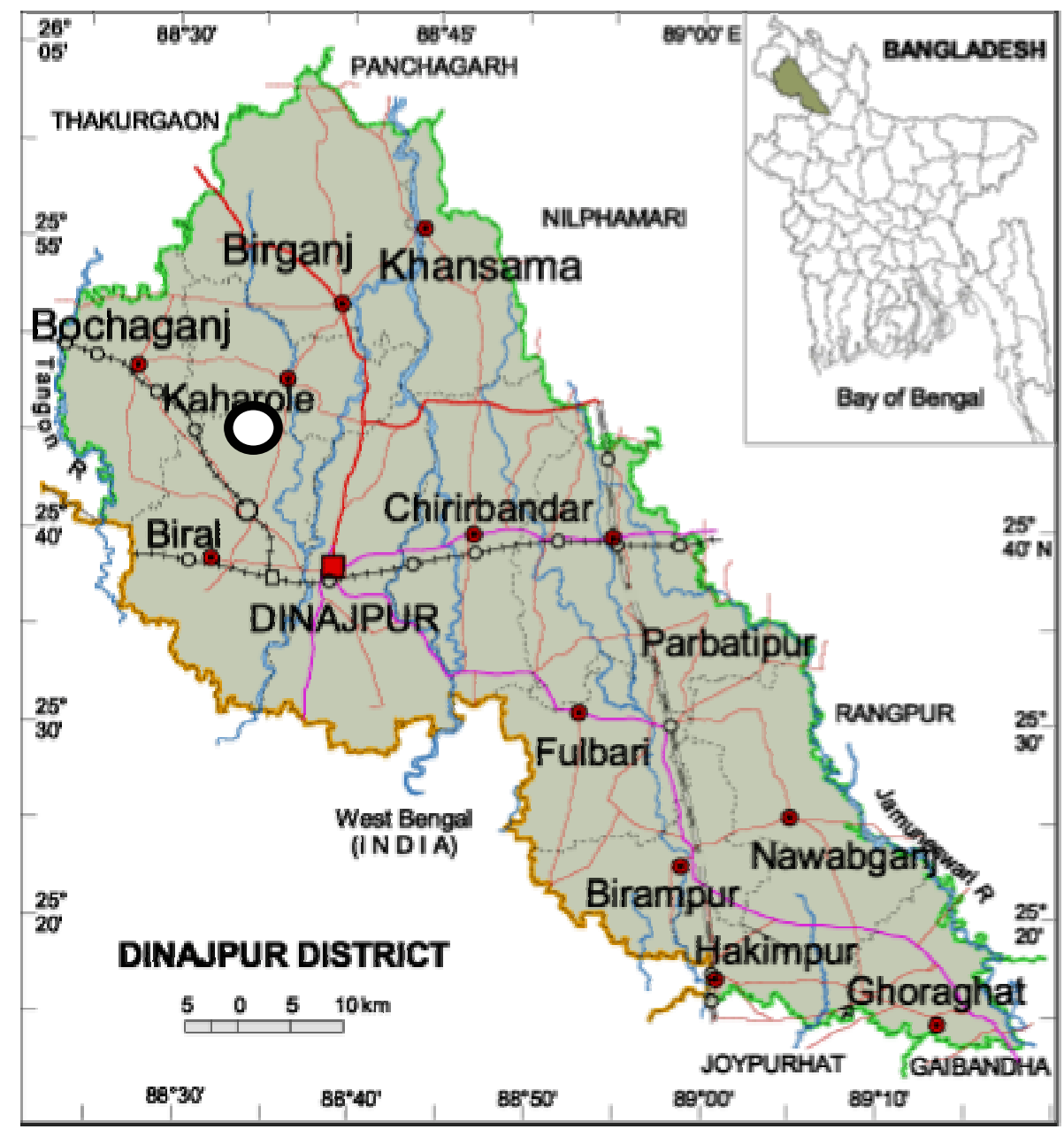

Fig. 1. Location of the study area (circled) in Kaharole, Dinajpur (source: www.banglapedia.org) 
The adivasi households in this village were given low-cost net cages and tilapia fry to rear in the cages in their ponds. The pond where cages were set was of 166 decimal in size with a depth of 1.2-1.8 m. This was relatively a large pond where seven cages were installed for conducting the study. There were about $150-200$ fish of $2.54 \mathrm{~cm}$ size in average stocked in each of the installed cages for rearing. After one and a half month of releasing the fry in cages, this study was started. Three cages were selected randomly and fishes were collected from the cages and put into the bucket with water and length and weight of 40 fishes were taken from each cage on the pond dike carefully. All together, 120 fishes were sampled and the data of length and weight of every individual was recorded. After this, fish were released to same cages again carefully.

The total length of fish was measured from the tip of the snout to the margin of the tail. The individual whole fish was measured as body weight. The total length was taken to the nearest $\mathrm{cm}$ with a measuring scale and the body weight was taken to the nearest $g$ with an electronic digital balance (CAMRY= Model: EK 3052).

The relationship between length and weight of fish can be adequately described by the cubic or power curve equation: $W=a L^{b}$, where $W$ is total body weight $(g), L$ is the total length $(\mathrm{cm}), a$ and $b$ are the coefficients of the functional regression between $\mathrm{W}$ and $\mathrm{L}$. Power curve equation can be transformed into linear form by the use of natural logarithms (symbolized as log). All data were log transformed and least squared linear regression performed with LogW $=\log a+\operatorname{bog} W(S c h n e i d e r, 2000)$. This equation was of the same form as the linear equation $Y=a+b X$. The value of LogW and Log $L$ equated to $Y$ and $X$ respectively, and Log $a$ and $b$ equated to the intercept and slope respectively. Thus the data were treated as a linear regression by plotting LogW against LogL. To express the degree of linear regression or correlation between two variables, the correlation coefficient, $r$, was estimated by the following formula with MS Excel:

$r=\left[n \sum X Y-\sum X \sum Y\right] / \sqrt{ }\left(\left[n \sum X^{2}-\left(\sum X\right)^{2}\right]\left[n \sum Y^{2}-\left(\sum Y\right)^{2}\right]\right)$

Along with length-weight relationship condition factor $(K)$ was determined to understand the health condition of fish. Generally, the fish is of fitting stoutness when it is of round and relatively thick shape. Undernourished or thin fish has a condition factor of less than 1. Adequately fed or fat fish has a condition factor greater than 1 . If the fish is not properly reared with required nutrition and feed then condition factor would be less than 1 . The condition factor $(K)$ of cage reared tilapia fingerling was determined using the following formula:

$\mathrm{K}=100 \mathrm{~W} / \mathrm{L}^{3}$ (Bannister, 1976)

Where $\mathrm{K}=$ Condition Factor, $\mathrm{W}=$ Weight in $\mathrm{g}$, and $\mathrm{L}=$ Length in $\mathrm{cm}$

\section{Analysis of the water quality parameters}

For water quality parameters and phytoplankton study, samples were also collected from Tarala village. Three water samples were collected from each of the cages and outside the cages i.e; from pond in which the cages were set up. The water samples were kept in separate clean white plastic bottles and each was marked properly. Water temperature, transparency dissolved oxygen, ammonia-nitrogen, phosphate-phosphorus; nitrate-nitrogen and $\mathrm{pH}$ were analyzed and recorded on the dike of the pond. For each parameter three samples were tested. Water temperature was measured using a Celsius thermometer. Water transparency was measured using secchi-disc. Dissolved oxygen (mg/l), Ammonianitrogen $(\mathrm{mg} / \mathrm{l})$, Phosphate-phosphorus $(\mathrm{mg} / \mathrm{l})$, Nitrate-nitrogen $(\mathrm{mg} / \mathrm{l})$ and $\mathrm{pH}$ were determined using Sera Kits purchased from local aqua-input suppliers.

The samples for plankton study from the cage installed pond in Tarala village were taken out in the Laboratory of water Quality and Pond Dynamics of the Department of Fisheries Management, Bangladesh Agricultural University, Mymensingh for in-depth observations. For qualitative study, $1 \mathrm{ml}$ of collected sample was examined using a Sedgewick-Rafter (S-R) cell and a binocular microscope (Swift, $\mathrm{M}-4000$ ) with phase contrast facilities. The Sedgewick-Rafter counting cell (S-R cell) is a special type of slide having a counting chamber which is $50 \mathrm{~mm}$ long, $20 \mathrm{~mm}$ wide and $1 \mathrm{~mm}$ deep; the volume of the chamber is $1 \mathrm{ml}$. The counting chamber is equally divided into 1000 fields, each having a volume of 0.001 $\mathrm{ml}$. After pouring the sample, counting chamber was covered with a cover slip in order to eliminate the air 
bubbles and left to stand for 15 minutes to allow plankton to settle. All planktonic cells or colony forming units occurring in 10 randomly chosen fields were identified and counted under a binocular microscope (Olympus, M-4000D, Japan). Taxa were identified to genus level using keys from APHA (1992) and Bellinger (1992).

\section{Data processing, analysis and interpretation}

Data were entered on the spreadsheet of the computer software, Microsoft Excel. Errors were detected and necessary corrections were made accordingly after data entry. Data were analyzed by using SPSS (Statistical Package for Social Science) windows version 11.5, which offered statistical tools applied to social science based research. Descriptive statistics including mean, standard deviation etc. were generated and presented in graphical and tabular forms.

\section{Results and Discussion}

\section{Length-weight relationship of tilapia fingerling in cage}

The total length and body weight of sampled tilapia varied from 9.5 to $16.9 \mathrm{~cm}$ and from 21 to $101 \mathrm{~g}$ respectively. A graph or scatter plot of the results of the length-weight relationship is presented in Fig. 2. In this figure, the total length appears as the independent variable on the $X$ - axis, and body weight is the dependent variable on the $\mathrm{Y}$-axis. The regression line revealed that the intercept and the slope of the collected sampled were -3.56 and 2.86 respectively (Fig. 2). The correlation coefficient $(r)$ and the coefficient of determination $\left(r^{2}\right)$ were 0.97 and 0.94 respectively. Sethuramalingam et al. (2008) found the value of correlation coefficient $(r)$ was 0.88056 for Puntius filamentosus and Shendge (2007) found the value of correlation coefficient ( $r$ ) of 0.983 for Cirrhinus reba. The coefficient in the present study indicated that there was a high degree of correlation between total length and body weight, since it was close to 1 , and its positive expression reflected positive slope. The correlation coefficient $(0.97)$ was greater than the critical value 0.195 (with 118 degrees of freedom), concluded that there is a significant linear relationship between total length and body weight of cage reared tilapia fingerling and the relationship was statistically significant at $95 \%$ confidence level which was representative for the population as a whole. The growth of fish in the cages was more or less isometric as the value of the $b$ is close to the 3 (Olurin and Aderibigbe, 2009). The coefficient of determination (0.94) suggested that $94.0 \%$ of the variation in body weight was due to variation in total length. It means that, the growth of fish inside the cage was the fish being culture within the pond system. This clearly indicated that growth of fish in the cage based production systems in earthen pond in northwest Bangladesh is encouraging for cage farming by the adivasi households.

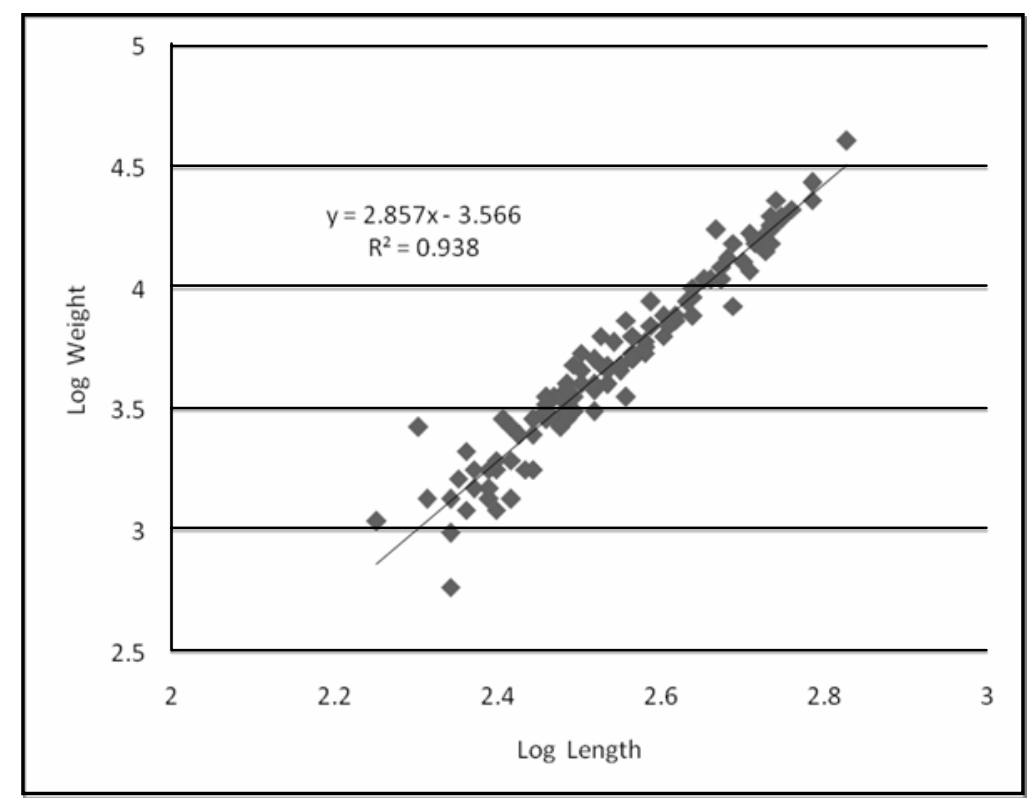

Fig. 2. The relationship between log length and log body weight of cage reared fish fingerling of tilapia 
The cage reared tilapia fingerling was classed into three categories in terms of their length and weight. The condition factors $\mathrm{K}$ was higher than 1 in all classes of fish (Table 1). As the condition factor was greater than 1, it can be concluded that fish reared in cages were in good condition and healthy. It also means that the growth of tilapia in cages was good as condition factor has been used as an index for growth studies (Fagade, 1979).

Table 1. Condition factor (K) of cage reared tilapia fingerling in ponds of Adivasi households

\begin{tabular}{|l|c|c|c|}
\hline Frequency (No. of tilapia) & Standard Length (SL) & Weight $(\mathrm{g})$ & Condition Factor (K) \\
\hline 39 & 11.12 & 27.79 & 2.02 \\
\hline 49 & 12.72 & 40.67 & 1.98 \\
\hline 32 & 15.11 & 67.41 & 1.95 \\
\hline
\end{tabular}

\section{Water quality parameters}

Water quality parameters of pond and cages were examined to observe any appreciable changes that might have occurred between pond and cages. The overall mean values of each water quality parameters as recorded from different sampling are presented in Table 2. One way analysis of variance (ANOVA) was performed on the data to observe whether any difference exists in different sampling or not.

The physico-chemical parameters as per different samplings did not vary indicating that the water quality parameters had equally affected inside and out side the cages. Water quality in broader sense includes all physical, chemical and biological characteristics of water. The existence, growth, production and wellbeing of aquatic life are mediated through a chain of interacting physical and chemical parameters of water. Moreover, water quality is directly related to the productivity of water body, the growth, production and survival of fish and other aquatic animals. In the present study, the water quality parameters including water temperature, transparency, dissolved oxygen, ammonia-nitrogen, phosphate-phosphorus, nitratenitrogen and $\mathrm{pH}$ were within the suitable range for fish culture (Table 2). Moreover, the water quality parameters in different cages were same as in the pond water suggesting that cage culture does not alter the pond environment in the adivasi communities. Akter (2007), Mazumdar et al. (1997), and BFRI (1994) found more or less similar ranges of water quality parameters in their studies. It indicates that cage culture does not affect the pond productivity. Moreover, the feed which is used for cage culture enhanced the productivity of pond that is used as feed by the stocked fish within the pond.

Table 2. Mean value with standard Error ( $\pm S E)$ of water quality parameters as recorded from inside of cages and outside of cages (pond)

\begin{tabular}{|l|c|c|c|c|}
\hline \multirow{2}{*}{ Water quality parameters } & \multicolumn{4}{|c|}{ Cage and pond } \\
\cline { 2 - 4 } & Cage-1 & Cage-2 & Cage-3 & Pond \\
\hline Temperature $\left({ }^{\circ} \mathrm{C}\right)$ & $30.0 \pm 0.0$ & $30.0 \pm 0.0$ & $30.0 \pm 0.0$ & $29.7 \pm 0.3$ \\
\hline Transparency $(\mathrm{cm})$ & $23.0 \pm 0.0$ & $23.0 \pm 0.0$ & $23.0 \pm 0.0$ & $23.3 \pm 0.3$ \\
\hline $\mathrm{DO}(\mathrm{mg} / \mathrm{l})$ & $5.3 \pm 0.3$ & $5.0 \pm 0.0$ & $5.0 \pm 0.0$ & $6.0 \pm 0.0$ \\
\hline $\mathrm{NH}_{3}(\mathrm{mg} / \mathrm{l})$ & $0.0 \pm 0.0$ & $0.0 \pm 0.0$ & $0.0 \pm 0.0$ & $0.0 \pm 0.0$ \\
\hline $\mathrm{PO}_{4}(\mathrm{mg} / \mathrm{l})$ & $1.0 \pm 0.0$ & $1.0 \pm 0.0$ & $1.0 \pm 0.0$ & $2.0 \pm 0.0$ \\
\hline $\mathrm{NO}_{2}(\mathrm{mg} / \mathrm{l})$ & $0.0 \pm 0.0$ & $0.0 \pm 0.0$ & $0.0 \pm 0.0$ & $0.0 \pm 0.0$ \\
\hline $\mathrm{pH}$ & $7.8 \pm 0.0$ & $7.4 \pm 0.0$ & $7.4 \pm 0.0$ & $7.4 \pm 0.0$ \\
\hline
\end{tabular}

According to qualitative study, the plankton population indicates the productive status of water, representing both direct and indirect sources of food for fish. Presence of plankton indicated the enrich status of water quality. In the present study, both phytoplankton and zooplankton were found available. The laboratory investigation showed that about 5 phyla and 25 genera of phytoplankton from Bacillariophyceae, Cyanophyceae, Chlorophyceae, Euglenophyceae and Rhodophyceae groups and one phylum and 5 genera of zooplankton from Rotifera group were found in cages installed in ponds. On the basis of genera number, the most dominant group was the Chlorophyceae ( 11 genera), followed by 
Cyanophyceae (6 genera), Bacillariophyceae (5 genera), Euglenophyceae ( 2 genera) and Rhodophyceae (1 genera) (Table 3). Taiyebi (2009), reported five major groups of phytoplankton that were Bacillariophyceae, Chlorophyceae, Cyanophyceae, Euglenophyceae and Rhodophyceae from old Brahmaputra river beside Bangladesh Agricultural University, Mymensingh campus where the most dominant group was Chlorophyceae and Rotifera. Hasan (2008) also found five major groups of phytoplankton which was Bacillariophyceae, Chlorophyceae, Cyanophyceae, Euglenophyceae and Rhodophyceae from the same river Brahmaputra. Therefore it could be argued that the cage installed ponds were nutrient rich and highly productive and cage culture did not affect pond productivity.

The growth performance of tilapia fingerling could be explained by the suitable water quality parameters in terms of physico-chemical, and biological aspects, particularly plankton productivity in the pond environment. Tilapias are considered filter feeders because they can efficiently harvest plankton from the water. They can digest more efficiently the plant protein (Popma and Masser, 1999). The main plankton genera found in tilapia stomach belongs to Cyanobacteria, Chlorophyceae, Bacillariophyceae and Euglenophyceae, Copepoda and Rotifers. The composition percentage of food items in stomach contents of tilapia was ranked as phytoplankton>detritus>zooplankton at all fish sizes (Abdel-Tawwab and ElMarakby, 2004). This was corroborated by Moriarty and Moriarty (1973) who reported that phytoplankton feeder Nile tilapia's total length was $6 \mathrm{~cm}$ whereas zooplankton feeder tilapia growth was $5 \mathrm{~cm}$. A study carried out by Teferi et al. (2000) showed equal growth of tilapia fed with phytoplankton and zooplankton.

Table 3. The type of phytoplankton and zooplankton genera identified in the cage and ponds

\begin{tabular}{|c|c|c|}
\hline \multicolumn{2}{|c|}{ Phytoplankton } & Zooplankton \\
\hline Bacillariophyceae & Chlorophyceae & Rotifera \\
\hline Fragillaria & Ankistrodesmus & Keratella \\
Cyclotella & Chlorella & Asplanchna \\
Navicula & Closterium & Notholca \\
Nitzchia & Oocystis & Tricocerca \\
Surirella & Pediastrum & \\
Cyanophyceae & Scenedesmus & \\
Anabaena & Tetraedron & \\
Spirulina & Ulothrix & \\
Gomphosphaeria & Spirogyra & \\
Microcystis & Sticococcus & \\
Oscillatoria & Closteridium & \\
Nostoc & Euglenophyceae & \\
& Euglena & \\
& Phacus & \\
& Rhodophyceae & \\
& Hildebrandia & \\
\hline
\end{tabular}

\section{Conclusion}

Cage culture is a simple and quick installable technique of aquaculture. Adivasi people who are resource poor can easily adopt cage base fish fingerling production. The growth performances of fish in cages were encouraging in terms of length-weight relationship and condition factor, and cage culture did not affect the pond productivity and vice versa. As a result, it could be concluded that the growth of tilapia in cages with higher productivity might be an important livelihood strategy of poor and marginal households in the society of Bangladesh. 


\section{References}

Abdel-Tawwab, M. and El-Marakby, H.I. 2004. Length-Weight relationship, natural food and feeding selectivity of Nile tilapia, Oreochromis niloticus (L) in fertilized earthen ponds. Central Laboratory for Aquaculture Research, Abbassa, AboHammad, Sharqia, Egypt. pp. 503-507.

Akter, S.R. 2007. Monthly abundance of phytoplankton in relation to water quality in nursery ponds. MS Thesis. Department of Aquaculture, Bangladesh Agricultural University, Mymensingh. pp. 57-60.

APHA, 1992. Standard Methods for the Examination of Water and Waste water, 18th ed. American Public Health Association, Washington, DC. 1268 p.

Bannister, J.V.C. 1976. The length-weight relationship, condition factor gut contents in the dolphin fish Coryphaena hippurus (L) in the Mediterranean J. Fish Biol., 9: 335-338.

Bellinger E.G. 1992. A Key to Common Algae. The Institute of Water and Environmental Management, London, $138 \mathrm{p}$.

BFRI. 1994. Mixed culture of fish pond, fisheries development techniques. Bangladesh Fisheries Research Institute, Mymensingh. $28 \mathrm{pp}$.

CARE. 2000. Successful Cage Aquaculture-Low input cage culture in Bangladesh. Care Bangladesh. pp. 3-28.

Fagade, S.O. 1979. Observation of the biology of two species of tilapia from the Lagos lagoon Nigeria. Bull. Inst. Fond Afr. Nore (Ser. A)., 41: 627-658

Haque, M.M., Barman, B.K. and Murshed-e-Jahan, K. 2010. Effectiveness of different pond access arrangements for cage based fish fingerling production by adivasi households. Policy Brief. The WorldFish Center, Bangladesh. 2 pp.

Hasan, A.N.G.M. 2008. Hydrographic status, natural food abundance and SIS biodiversity in matshyarani fish sanctuary. MS Thesis. Department of Fisheries Biology and Genetics, Bangladesh Agricultural University, Mymensingh. 46 pp.

Kamal, M., Samad, M. and Banu, N. 2003. Santal community in Bangladesh- problems and prospects. Research and Development Collective,_Dhaka. 80 pp.

Mazumder, S., Sengupta, A., Pati, K., Sengupta, K.K. and Santra, S.C. 1997. Water quality, plankton and periphyton assessment in different waterbody in West Bengal (India). In: K.K. Vass and M. Sinha (eds.) Changing perspectives of inland fisheries, proceeding of the national seminar March 16-17, IFSI, Barrackpore, India. pp. 187-190.

Mendes, B., Fonseca, P. and Campos, A. 2004. Weight-length relationships for 46 fish species of the Portuguese west coast. J. Applied Icht., 20: 355-361.

Morato, T., Afonso, P., Loirinho, P., Barreiros, J.P., Sanstos, R.S. and Nash, R.D.M. 2001. Length-weight relationships for 21 costal fish species of the Azores, North-eastern Atlantic. Fisheries Rese., 50: 297-302.

Moriarty, D.J.W. and Moriarty, C.M. 1973. The assimilation of carbon from phytoplankton by two herbivorous fishes: Tilapia nilotica and Haplochromis nigripinnis. J. Zool., Lond., 171: 41-55.

Olurin, K.B. and Aderibigbe, O.A. 2009. Length-weight relationship and condition factor of pond reared juvenile Oreochromis niloticus. J. Zool., 1 (2): 82-85.

Popma, T and Masser, M. 1999. Tilapia, life history and biology. SRAC (Southern Regional Aquaculture Center) Publication No. 283.

Schneider, J.C., Laarman, P.W. and Gowing, H. 2000. Length-weight relationships. Chapter 17 in Schneider, James C. (ed.) 2000. Manual of fisheries survey methods II: with periodic updates. Michigan Department of Natural Resources, Fisheries Special Report 25, Ann Arbor. 1 pp.

Sethuramalingam, T.A., Ranjan, D. Sudhakaran, M., Ananth, Y. and Rajakumari, K. 2008. Length-weight relationship and fecundity analysis of fresh water barb Puntius filamentosus (valenciennes) from river Thamiraparani. Environ. Ecol., 26 (1): $414-$ 421.

Shendge, A.N. 2007. Length-weight relationship and relative condition factor in Cirrhinus reba (Hamilton). J. Experiment. Zool., 10 (2): 309-31.

Taiyebi, K.A. 2009. Effect of a fish sanctuary, "The Matshyarani" on the water quality parameters, natural food abundance and fish biodiversity in the river old Brahmaputra. MS Thesis. Department of Fisheries Biology and Genetics, Bangladesh Agricultural University, Mymensingh. $45 \mathrm{pp}$.

Teferi, Y., Admassu, D. and Mengistou, S. 2000. The food and feeding habit of Oreochromis niloticus (L) (Pisces: Cichlidae) in Lake Chamo, Ethiopia. Ethiopian J. Sci., 23 (1): 1-12. 